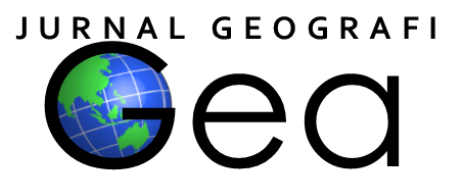

\title{
PEMETAAN DAN ANALISIS PROBABILISTIC SEISMIC HAZARD ANALYSIS (PSHA) RADIUS 500 KM DARI DENPASAR
}

\author{
I Putu Dedy Pratama ${ }^{1}$ \\ ${ }^{1}$ BMKG Stasiun Geofisika Denpasar \\ ${ }^{1}$ checkmate_mail@yahoo.co.id
}

\begin{abstract}
Denpasar is the most populous area in Bali. This also makes a lot of infrastructure built in this area. As a city that is prone to earthquakes, Denpasar City must have a Probabilistic Seismic Hazard Analysis (PSHA) map. If studied from the significant earthquakes that shook Denpasar was in the Benioff zone or deep background with the depth of the earthquake being more than $50 \mathrm{~km}$. This study took the study area in the city of Denpasar and surrounding areas. Radius taken at $500 \mathrm{~km}$ are measured from the Denpasar Geophysical Station, which is in the center of Denpasar City at coordinates latitude -6,68 and longitude 115,21 so that coordinates are obtained from latitude -12,96 till -5,50 and longitude 110,66 till 119,75 BT. Seismic hazard analysis is carried out with the help of the USGS-PSHA program by taking into account the sources of the earthquakes that occurred in the Bali and surrounding regions. The results of the analysis of the PSHA calculation show that the longer the measurement time span, the higher the value of shocks obtained. The value of Peak Ground Acceleration (PGA) in the bedrock of the Denpasar area within a $500 \mathrm{~km}$ radius for a probability of exceeding $10 \%$ in 50 years ranges from $0,05 \mathrm{~g}-0,4 \mathrm{~g}$. Denpasar has $P G A$ value for $T=1 \mathrm{~s}$ in the range 0,1 $0,15 \mathrm{~g}$ and for $T=0,2 \mathrm{~s}$ in the range 0,3-0,4 $\mathrm{g}$. There is a slight difference between the results of the study with the Peta Gempa Indonesia 2017 about 0,1 g. This is because there are differences in the data used.
\end{abstract}

Keywords: Denpasar, earthquakes, PSHA, probability

\begin{abstract}
ABSTRAK
Denpasar merupakan daerah terpadat penduduknya di Bali. Hal ini juga membuat banyak infrastruktur dibangun di daerah ini. Sebagai kota yang rawan terhadap bencana gempabumi Kota Denpasar harus memiliki peta Probabilistic Seismic Hazard Analysis (PSHA). Jika ditinjau dari gempabumi signifikan yang mengguncang Denpasar berada pada zona Benioff atau deep background dengan kedalaman gempabumi berada lebih dari $50 \mathrm{~km}$. Penelitian ini mengambil wilayah kajian di Kota Denpasar dan sekitarnya. Radius yang diambil sebesar $500 \mathrm{~km}$ diukur dari Stasiun Geofisika Denpasar yang berada di pusat Kota Denpasar yaitu pada koordinat 6,68 LS dan 115,21 BT sehingga diperoleh batasan koordinat 12,96 LS - 5,50 LS dan 110,66 BT - 119,75 BT. Analisis seismik hazard dilakukan dengan bantuan program USGS-PSHA dengan memperhatikan sumbersumber gempabumi yang terjadi di wilayah Bali dan sekitarnya. Hasil analisis perhitungan PSHA menunjukan bahwa semakin panjang rentang waktu pengukuran maka nilai guncangan yang diperoleh akan semakin tinggi. Nilai percepatan tanah maksimum di batuan dasar wilayah Denpasar dalam radius $500 \mathrm{~km}$ untuk probabilitas terlampaui $10 \%$ dalam 50 tahun berkisar 0,05 g - 0,4 g. Kota Denpasar memiliki nilai PGA untuk $\mathrm{T}=1 \mathrm{~s}$ pada rentang $0,1-0,15 \mathrm{~g}$ dan untuk $\mathrm{T}=0,2 \mathrm{~s}$ pada rentang $0,3-0,4 \mathrm{~g}$. Terdapat sedikit
\end{abstract}


perbedaan antara hasil penelitian dengan Peta Gempa Indonesia 2017 sekitar 0,1 g. Hal ini karena terdapat perbedaan data yang digunakan.

Kata kunci: Denpasar, gempabumi, PSHA, probabilitas

\section{PENDAHULUAN}

Kota Denpasar merupakan ibukota dari Provinsi Bali. Wilayah Denpasar merupakan daerah terpadat penduduknya di Bali. Hal ini juga membuat banyak infrastruktur dibangun di daerah ini. Secara geologi batuan dasar wilayah Denpasar merupakan formasi batuan gunungapi kelompok Buyan-Bratan dan Batur yang terdiri dari aglomerat, lava dan tuf, dan sedikit lahar ignimbrite yang dihasilkan oleh Gunung Batur saat masih aktif. Pada bagian pesisir tenggara merupakan formasi aluvium yang terdiri dari kerakal, kerikil, pasir, lempung, serta endapan sungai dan pantai dengan karakter pasirnya yang putih (Hadiwidjojo, 1998).

Wilayah Bali merupakan daerah yang memiliki seismisitas cukup tinggi. Dalam satu hari wilayah ini mengalami rata-rata 10-20 kali gempabumi. Generator utama gempabumi di wilayah ini adalah zona pertemuan lempeng Indoaustralia dan Eurasia yang memiliki kecepatan $4 \mathrm{~cm} /$ tahun (Pusgen, 2017) yang berada di wilayah selatan Pulau Bali dan patahan busur belakang di wilayah utara Pulau Bali. Kedua generator ini merupakan penyebab gempabumi merusak yang pernah terjadi di wilayah ini.

Sebagai kota yang rawan terhadap bencana gempabumi Kota Denpasar harus memiliki peta PSHA. Penelitian oleh Nugraha, dkk. (2014) menyatakan bahwa Sumber gempabumi yang memberikan kontribusi hazard terbesar adalah deep background. Nilai dari Peak Ground Acceleration (PGA) dari kurva hazard yang dihasilkan untuk Kota Denpasar juga relatif kecil.

Jika ditinjau dari gempabumi signifikan yang mengguncang Denpasar berada pada zona Benioff atau deep background dengan kedalaman gempabumi berada lebih dari 50 $\mathrm{km}$. Salah satu contoh yang terjadi pada tahun lalu adalah gempabumi Nusa Dua pada 22 Maret 2017. Parameter gempabumi ini sesuai dengan rilis BMKG gempabumi memiliki magnitudo 5,6 berlokasi di laut $12 \mathrm{~km}$ Tenggara Denpasar - Bali, dengan koordinat pusat gempabumi 8,79 LS 115,19 BT.
Gempabumi tersebut memiliki kedalaman sekitar $125 \mathrm{~km}$. Gempabumi ini menyebabkan kerusakan ringan.

Selain itu, zona megathrust juga pernah mengguncang Denpasar dengan potensi merusak pada 13 Oktober 2011 pukul 10:16:27 WIB yang terjadi dengan magnitudo 6,8 dan berada pada kedalaman $10 \mathrm{~km}$ dengan koordinat, 9.89 LS-114.53 BT. Ini merupakan gempabumi megathrust yang mengguncang Denpasar selama abad 21. Berdasarkan jarak terdekat titik terhadap bidang zona ini berjarak $71 \mathrm{~km}$ dari Kota Denpasar.

Untuk itu, perlu dilakukan pengukuran potensi gempabumi signifikan yang terjadi di wilayah Bali khususnya kota Denpasar. Untuk mengurangi dampak hazard gempabumi tersebut, upaya mitigasi perlu dilakukan secara dini dan optimal. Salah satu upaya mitigasi yang perlu dilakukan adalah dengan membuat peta hazard gempabumi, juga peta hazard yang menggambarkan efek gempabumi pada suatu lokasi yang akan membantu dalam rangka antisipasi dan mengurangi korban jiwa maupun kerugian materi.

Penelitian ini mengambil wilayah kajian di Kota Denpasar dan sekitarnya. Radius yang diambil sebesar $500 \mathrm{~km}$ diukur dari Stasiun Geofisika Sanglah Denpasar yang berada di pusat Kota Denpasar yaitu pada koordinat 6,68 LS dan 115,21 BT sehingga diperoleh batasan koordinat 12,96 LS - 5,50 LS dan 110,66 BT - 119,75 BT. Radius 500 km diambil berdasarkan tingkat probabilitas gempabumi maksimum yang berpotensi menimbulkan kerusakan di Kota Denpasar.

Data yang digunakan berdasar dari katalog BMKG yang telah direlokasi dari tahun 1900 hingga 2017 pada kedalaman 0 $300 \mathrm{~km}$ dengan radius episenter $500 \mathrm{~km}$ dari Kota Denpasar. Data ini sudah dilakukan penyeragaman magnitudo menjadi magnitudo skala momen $(\mathrm{Mw})$. Penggunaan batasan kedalaman $300 \mathrm{~km}$ ini karena untuk gempabumi maksimum di atas $300 \mathrm{~km}$ tidak berpotensi menimbulkan kerusakan di wilayah Denpasar. 
Parameter input lainnya adalah parameter subduksi wilayah Jawa dan Banda, parameter patahan di radius $500 \mathrm{~km}$ dari Kota Denpasar yang akan digunakan sebagai parameter input dalam pengolahan nilai PGA untuk sumber gempabumi subduksi dan patahan.

Adapun tujuan dari penelitian ini adalah untuk menganalisis hazard gempa yang disajikan dalam nilai percepatan tanah maksimum di batuan dasar untuk wilayah Bali dan sekitarnya pada kondisi Peak Ground Acceleration (PGA) untuk probabilitas terlampaui $10 \%$ dalam 50 tahun atau setara dengan periode ulang gempabumi 475 tahun. Penelitian hazard gempabumi untuk wilayah Indonesia sebelumnya telah dilakukan oleh Pusat Studi Gempa Nasional (Pusgen, 2017).

\section{METODE PENELITIAN}

Penelitian ini menggunakan lima tahapan metode dalam pengolahan data. Data gempabumi dipilih berupa gempabumi utama. Penentuan gempabumi utama (mainshock) dari gempabumi rintisan (foreshock) dan gempabumi susulan (aftershock) menggunakan kriteria rentang waktu dan rentang jarak berdasarkan metode empiris yang dibuat oleh Gardner dan Knopoff (1974). Pemisahan gempabumi utama dilakukan dengan bantuan program ZMAP (Wiemer, 2001) yang dijalankan menggunakan perangkat lunak Matlab. Hasil decluster ditunjukan pada Gambar 1.

Pemodelan sumber gempabumi yang dipergunakan dalam penelitian ini sama dengan yang dipergunakan dalam pembuatan Peta Gempabumi Indonesia 2017 (Pusgen, 2017). Dalam penelitian ini, sumber-sumber gempabumi yang dipergunakan merujuk pada program Probabilistic Seismic Hazard Analysis (PSHA) dari USGS (Harmsen, 2010) yang dikembangkan oleh Bella (2008).

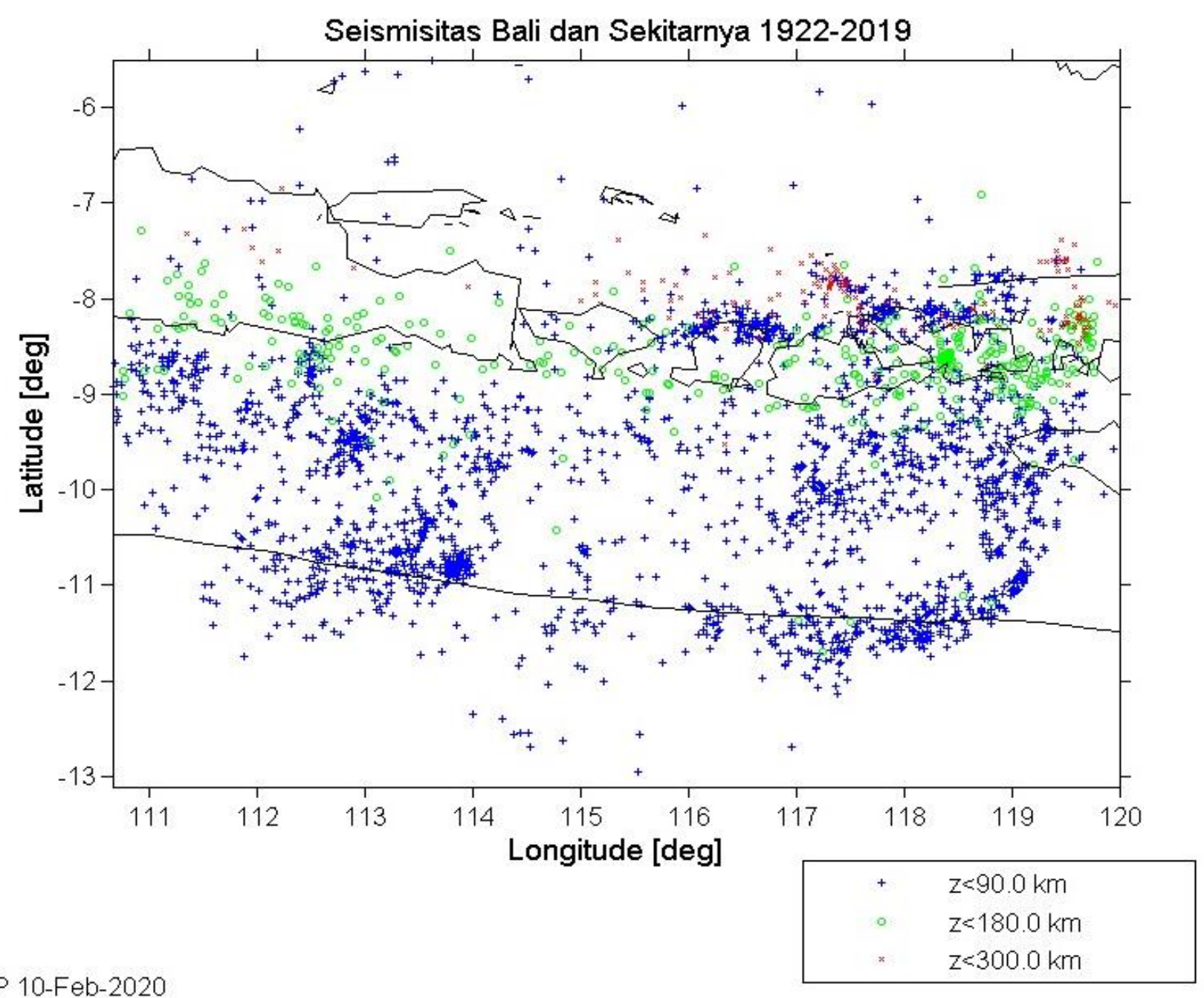

Gambar 1. Seismisitas radius $500 \mathrm{~km}$ dari Kota Denpasar yang telah di decluster. 
Metode PSHA dikembangkan oleh Cornell (1968), kemudian dilanjutkan oleh Merz dan Cornell (1973). Model dari analisis dan teknik perhitungannya yang terus dikembangkan hingga memiliki empat tahapan pengolahan data yaitu a) identifikasi sumber gempabumi, b) karakterisasi sumber gempabumi, c) pemilihan fungsi atenuasi, dan d) perhitungan bahaya gempabumi. Teori ini mengasumsikan magnitudo gempabumi $\mathrm{M}$ dan jarak R sebagai variabel acak independen yang menerus. Dalam bentuk umum teori probabilitas total ini dapat dinyatakan sebagai berikut :

$$
P[I \geq i]=
$$

$$
\int_{r} \int_{m} P[I \geq i \mid m \text { dan } r] f_{M}(m) f_{R}(r) d m d r
$$

dimana :

$\mathrm{fM}$ : fungsi distribusi dari magnitudo

fR : fungsi distribusi dari jarak hiposenter $\mathrm{P}[\mathrm{I} \geq \mathrm{i} \mid \mathrm{m}$ dan $\mathrm{r}]$ : probabilitas bersyarat dari intensitas I yang melampaui nilai i pada suatu lokasi yang ditinjau untuk kejadian gempa dengan magnitudo $\mathrm{M}$ dan jarak hiposenter $\mathrm{R}$.

Dalam pembuatan PSHA, zona sumber gempabumi diklasifikasikan kedalam tiga jenis yaitu: (1) sumber gempabumi sesar (fault), yaitu zona kejadian gempabumi yang terjadi pada patahan-patahan yang sudah terdefinisi dengan jelas, termasuk mekanisme, slip rate, dip, panjang patahan dan lokasinya. (2) Sumber gempabumi subduksi, yaitu zona kejadian gempabumi yang berada di dekat batas pertemuan antara lempeng samudera yang menunjam masuk ke bawah lempeng benua. Sumber gempabumi subduksi dibatasi hingga kedalaman $50 \mathrm{~km}$ atau daerah megathrust. Gempabumi dengan kedalaman lebih dari $50 \mathrm{~km}$ akan dinyatakan sebagai sumber gempabumi deep background. (3) Sumber gempabumi background (gridded seismicity), yaitu sumber gempabumi yang belum diketahui secara jelas, tetapi pada tempat tersebut didapati adanya beberapa kejadian gempabumi. Model sumber gempabumi ini diklasifikasikan menjadi dua yaitu shallow background (kedalaman hingga $50 \mathrm{~km}$ ) dan deep background (kedalaman lebih dari $50 \mathrm{~km}$ ). Model sumber gempabumi deep background sendiri dibagi dalam empat interval yaitu kedalaman 50-100 km, 100-150 $\mathrm{km}, 150-200 \mathrm{~km}$, dan 200-300 km. Model sumber gempabumi background mempergunakan katalog gempabumi utama yang telah dihilangkan gempabumi akibat subduksi dan gempabumi pada daerah sesar.

Tabel 1. Fungsi atenuasi yang digunakan dalam penelitian

Model Sumber Gempabumi

Shallow Backgroud

Deep Background

Sesar

Subduksi
Rumus Atenuasi

1. Boore and Atkinson, 2008

2. Campbell \& Bozorgnia, 2008

3. Chiou and Youngs, 2008

1. Atkinson and Boore, 1995

2. Youngs et al, 1997

3. Atkinson and Boore, 2006

1. Youngs et al, 1997

2. Campbell \& Bozorgnia, 2006

3. Chiou and Youngs, 2006

1. Youngs et al, 1997

2. Atkinson \& Boore, 2003

3. Zhao et al, 2006 dengan variable Vs-30 Sumber: Asrurifak, dkk., 2010 
Setelah gempabumi utama dipisahkan berdasarkan sumbernya, kemudian dicari nilai parameter seismisitas kegempabumian masing-masing untuk gempabumi background dan subduksi meliputi nilai a dan b serta Magnitude completeness (Mc) dengan metode least square (Gutenberg \& Richter, 1994) yang dijalankan menggunakan program ZMAP.

Salah satu langkah dasar dalam Seismic Hazard Analysis (SHA) adalah penentuan fungsi atenuasi (Ground Motion Prediction Equations/GMPE). Fungsi atenuasi merupakan persamaan yang dapat digunakan dalam mengestimasi tingkat goncangan tanah akibat gempabumi dengan magnitudo, jarak hiposenter, dan kondisi sumber gempabumi tertentu. Fungsi atenuasi yang digunakan dalam penelitian ini dibuat berdasarkan rumus atenuasi pada Tabel 1. dilakukan menggunakan pendekatan logic tree yang menyediakan penggunaan model alternatif. Salah satunya adalah memberikan faktor pembobot yang diinterpretasikan sebagai kemungkinan relatif dari model untuk menjadi benar (Asrurifak, 2010). Pemakaian logic tree disesuaikan dengan model sumber gempabumi yang dipergunakan. Analisis bahaya seismik dilakukan dengan bantuan program USGS-PSHA (Harmsen, 2010). Hasil nilai PGA disajikan menggunakan perangkat lunak ArcMap 2010.

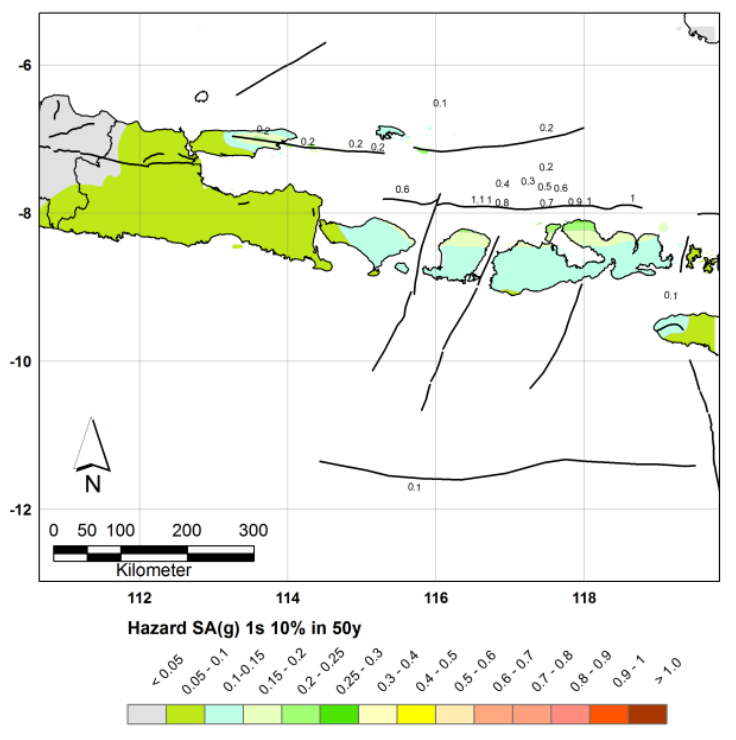

Pengelolaan unsur ketidakpastian

\section{HASIL DAN PEMBAHASAN}

Hasil analisis perhitungan PSHA menunjukan bahwa semakin panjang rentang waktu pengukuran maka nilai guncangan yang diperoleh akan semakin tinggi. Hal ini karena semakin panjang waktu data katalog gempabumi maka semakin banyak gempabumi dengan magnitudo besar yang akan muncul.

Terdapat tiga jenis nilai PGA yang diperoleh yaitu PGA batuan dasar (bedrock) dengan periode $\mathrm{T}=0 \mathrm{~s}, \mathrm{~T}=0.2 \mathrm{~s}$ untuk periode pendek, dan $\mathrm{T}=1 \mathrm{~s}$ untuk periode panjang. Setiap periode percepatan mewakili periode getaran struktur untuk masing-masing tingkatan. Misal, pada T=0s, maka akan cukup berpengaruh pada getaran pondasi bangunan. Pada $\mathrm{T}=0,2 \mathrm{~s}$ digunakan untuk mewakili periode getar struktur terpendek (bangunan 2 tingkat), sedangkan $\mathrm{T}=1 \mathrm{~s}$ berpengaruh pada guncangan di gedung bertingkat hingga 10 lantai. Apabila bangunan gedung tersebut berdiri pada wilayah dengan nilai percepatan tanah di permukaan yang cukup tinggi serta memiliki periode alami struktur yang sama dengan periode gempabumi, maka dapat dipastikan terjadi amplifikasi dan resonansi yang menyebabkan gedung tersebut kemungkinan mengalami simpangan dan terancam runtuh (BSN, 2012).

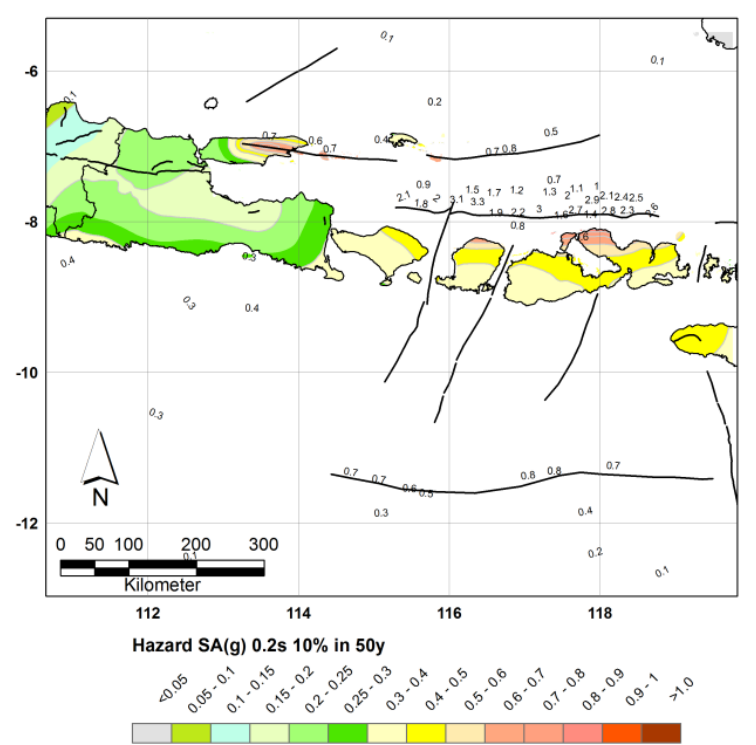

Gambar 2. Peta percepatan spektrum respon 1 detik (kiri) dan 0,2 detik (kanan) di batuan dasar (SB) untuk probabilitas terlampaui 10\% dalam 50 tahun (periode ulang 500 tahun) radius $500 \mathrm{~km}$ dari Kota Denpasar 
Secara keseluruhan, nilai percepatan tanah maksimum $\mathrm{T}=0,2$ menunjukan nilai yang lebih besar daripada $\mathrm{T}=0$ (Gambar 2). Rentang nilai PGA yang berdasarkan pada hasil peta (Gambar 2), dengan periode ulang 500 tahun untuk $\mathrm{T}=0,2 \mathrm{~s}$ adalah $0,85-0,75 \mathrm{~g}$ dan untuk $\mathrm{T}=1 \mathrm{~s}$ adalah $0,05-0,35 \mathrm{~g}$. Nilai tertinggi berada di bagian utara Pulau Lombok dan utara Pulau Sumbawa. Sesar Flores Back Arc mendominasi pengaruh pada nilai PGA pada $\mathrm{T}=0,2 \mathrm{~s}$, terlihat wilayah Jawa Timur dan Sumba memiliki nilai $\mathrm{PGA} \mathrm{T}=1 \mathrm{~s}$ yang paling rendah karena paling jauh dari Sesar Flores Back Arc. Untuk PGA $\mathrm{T}=0,2 \mathrm{~s}$ menunjukan nilai yang lebih bervariasi. Meskipun nilai PGA dari pengaruh Sesar Flores Back Arc masih tertinggi namun untuk wilayah lain sesar terdekat mempengaruhi nilai PGA masingmasing wilayah.

Kota Denpasar memiliki nilai PGA untuk $\mathrm{T}=1$ s pada rentang $0,1-0,15 \mathrm{~g}$ dan untuk $\mathrm{T}=0,2 \mathrm{~s}$ pada rentang $0,3-0,4 \mathrm{~g}$. Nilai ini mencerminkan nilai rata-rata PGA untuk wilayah Bali.

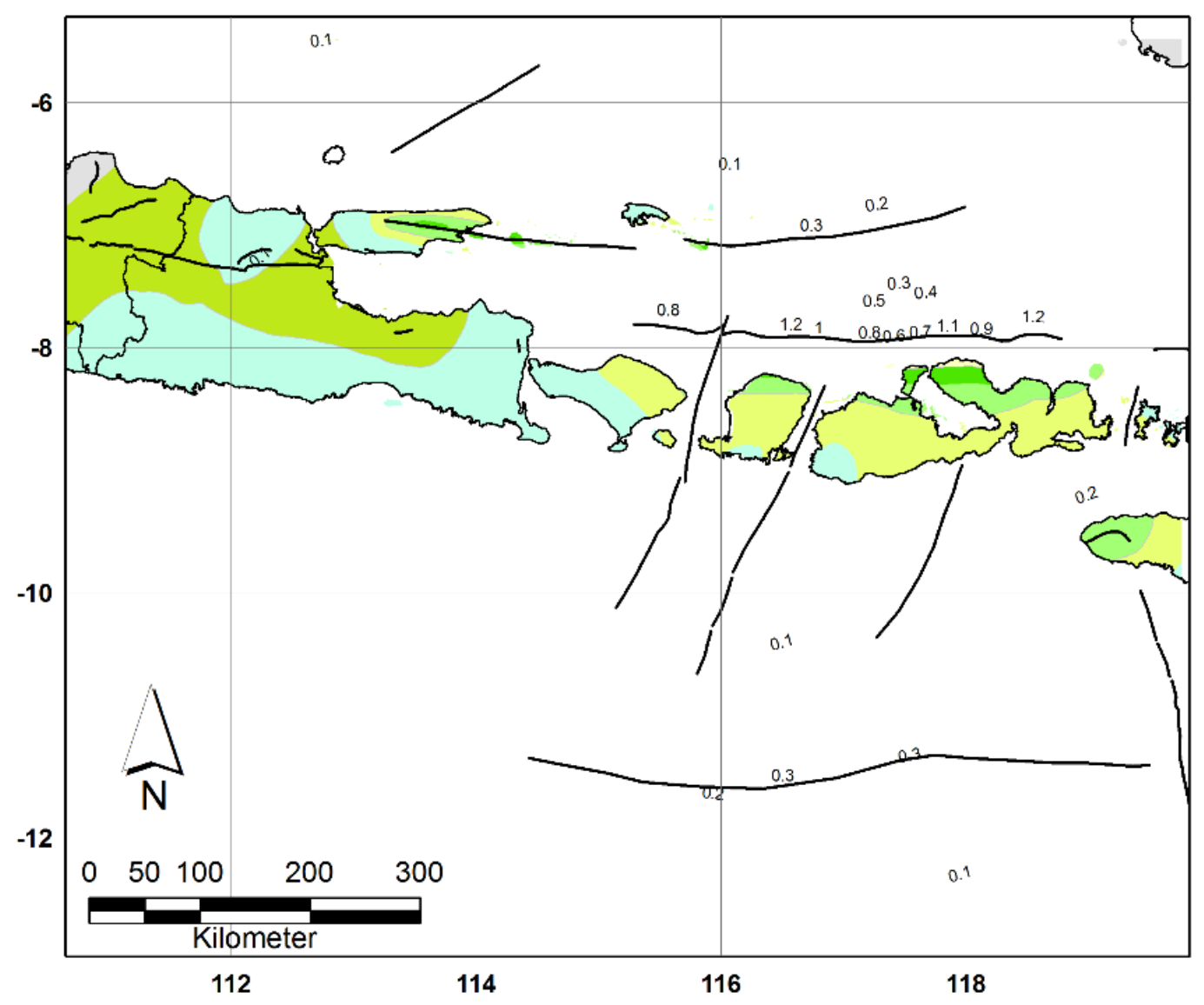

Hazard PGA(g) $10 \%$ in 50y

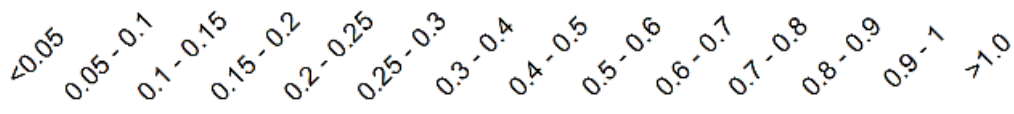

Gambar 3. Peta percepatan puncak di batuan dasar (SB) untuk probabilitas terlampaui 10\% dalam 50 tahun radius $500 \mathrm{~km}$ dari Kota Denpasar

Nilai percepatan tanah maksimum di batuan dasar di wilayah Bali berkisar antara $0,05 \mathrm{~g}-0,4 \mathrm{~g}$ (Gambar 3). Daerah-daerah yang mempunyai nilai percepatan tanah cukup tinggi adalah daerah yang berdekatan dengan sumber gempabumi sesar dan subduksi.

Secara umum guncangan gempabumi di Bali dan sekitarnya akan lebih besar pada daerah yang berdekatan dengan zona penunjaman dan sesar aktif. Hal ini terlihat dari tingginya PGA di utara Lombok, Sumbawa, dan Bali akibat dari sesar aktif Flores Back Arc segmen. Selain itu pada Pulau Madura nilai guncangan tinggi diakibatkan oleh keberadaan sesar RMKS segmen Barat yang melewati Pulau Madura. 
Wilayah Jawa Bagian timur dan Bali baratdaya umumnya memiliki nilai guncangan yang lebih rendah. Hal ini karena keberadaannya yang jauh dari sesar aktif. Nilai guncangan gempabumi akan menurun seising dengan pertambahan jarak dari zona penujaman sehingga terlihat gradasi penurunan pada Pulau Sumba. Di daerah dengan sesar aktif terlihat bahwa sesar Flores Back Arc mendominasi nilai PGA sepanjang utara busur kepulauan Nusa Tenggara. Hal ini sesuai dengan penelitian Kurniawan, dkk. (2019) yang menyatakan bahwa nilai PGA Pulau Lombok disebabkan oleh kontribusi efek Subduksi Sumba dan sesar Flores Back Arc.

Jika dibandingkan dengan hasil analisis oleh Pusat Studi Gempa Nasional (2017) nilai percepatan puncak di batuan dasar berkisar antara $0,15 \mathrm{~g}-0,5 \mathrm{~g}$ (Gambar 3). Secara umum, rentang nilai penelitian relatif sama dengan hasil Pusgen (2017). Untuk daerah dekat sesar aktif seperti utara Sumbawa dan Lombok, nilai percepatan tanah puncak di batuan dasar menunjukan nilai yang sama. Secara keseluruhan, pola gradasi warna dari hasil interpolasi menunjukan kemiripan dengan Peta Pusgen 2017.

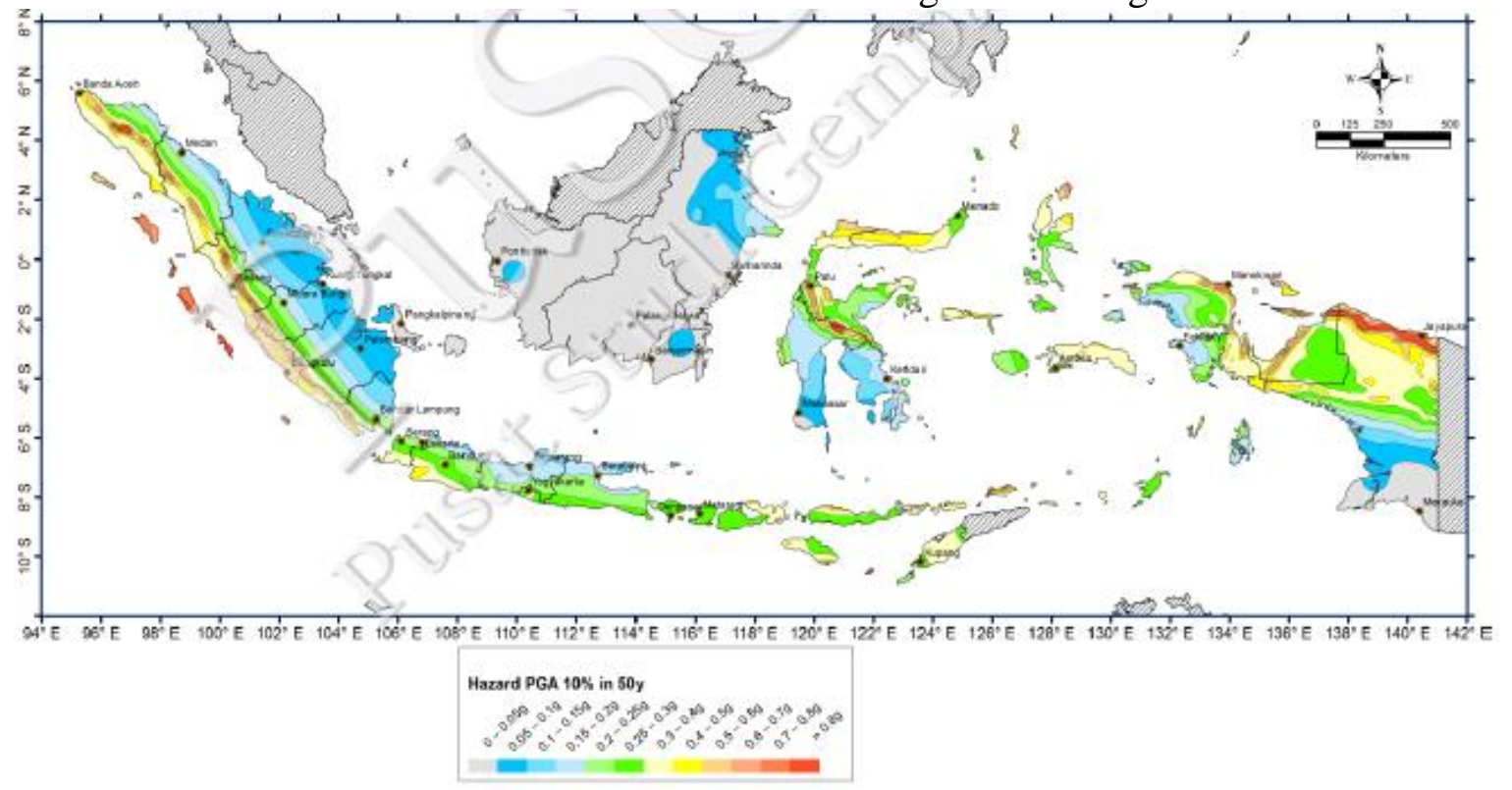

Gambar 3. Peta percepatan puncak di batuan dasar (SB) untuk probabilitas terlampaui 10\% dalam 50 tahun (Pusgen, 2017).

Untuk Pulau Jawa bagian timur nilai percepatan penelitian memiliki sedikit perbedaan dengan Peta Pusgen 2017. Pada wilayah selatan Nilai PGA hasil penelitian lebih rendah tetapi pada bagian utara nilainya lebih tinggi khususnya pada Pulau Madura.

Pada Pulau Bali secara keseluruhan hasil penelitian lebih rendah daripada Peta Pusgen 2017. Namun, pola petanya sama, dimana Pulau Bali hanya terbagi atas dua wilayah percepatan berbeda dengan garis batas membentang dari baratlaut ke tenggara.

Pada wilayah Lombok dan Sumbawa secara keseluruhan nilai percepatan penelitian lebih rendah. Demikian juga untuk wilayah Sumba hasil penelitian sedikit lebih rendah dibandingkan dengan Peta Pusgen 2017.

Perbedaan hasil penelitian dengan Peta Pusgen 2017 karena perbedaan data yang digunakan. Pada Pusgen 2017 menggunakan data Indonesia secara keseluruhan. Sedangkan, pada penelitian data dibatasi dengan radius 500 km dari Kota Denpasar. Hal ini mempengaruhi nilai parameter input yang digunakan seperti nilai a dan b serta magnitudo completeness pada pengolahan parameter gempabumi subduksi dan background.

\section{SIMPULAN}

Rentang nilai PGA untuk wilayah radius $500 \mathrm{~km}$ dari Denpasar dengan periode ulang 500 tahun untuk $\mathrm{T}=0,2 \mathrm{~s}$ adalah $0,85-$ $0,75 \mathrm{~g}$ dan untuk $\mathrm{T}=1 \mathrm{~s}$ adalah $0,05-0,35 \mathrm{~g}$. Nilai tertinggi berada di bagian utara Pulau Lombok dan utara Pulau Sumbawa.

Nilai percepatan tanah maksimum di batuan dasar wilayah Denpasar dalam radius $500 \mathrm{~km}$ untuk probabilitas terlampaui $10 \%$ 
dalam 50 tahun berkisar $0,05 \mathrm{~g}-0,4 \mathrm{~g}$. Secara umum, rentang nilai percepatan tersebut relatif hampir sama dengan Peta Gempa Indonesia 2017. Terdapat sedikit perbedaan antara hasil penelitian dan Peta Gempa Indonesia 2017 sekitar $0,1 \mathrm{~g}$. Hal ini karena terdapat perbedaan data yang digunakan. Pada Pusgen 2017 menggunakan data Indonesia secara keseluruhan hingga tahun 2017 sedangkan pada penelitian data dibatasi dengan radius 500 km dari Kota Denpasar hingga tahun 2019.

\section{REKOMENDASI}

Pemetaan wilayah dengan analisis probabilitas bahaya gempabumi sangat perlu dilakukan karena berperan penting dalam mitigasi bencana khususnya dalam penentuan kualitas struktur bangunan agar tahan menghadapi gempabumi dan efisien dalam biaya.

\section{DAFTAR PUSTAKA}

Asrurifak, M., Irsyam, M., Budiono, B., Triyoso, W., Hendriyawan. (2010). Development of Spectral Hazard Map for Indonesia with a Return Period of 2500 Years using Probabilistic Method. Civil Engineering Dimension, Vol. 12, No. 1, hal 52-62 ISSN 1410-9530 print / ISSN 1979-570X online

Asrurifak, M. (2010), Peta Respon Spektra Indonesia Untuk Perencanaan Struktur Bangunan Tahan Gempa Dengan Model Sumber Gempa Tiga Dimensi Dalam Analisa Probabilitas, Disertasi Program Doktor, Institut Teknologi Bandung.

Atkinson, G.M., Boore, D.M. (2003). Empirical GroundMotion Relations for Subduction Zone Earthquakes and Their Application to Cascadia and Other Regions, Bull. Seismol. Soc. Am., Vol. 93, no. 4, pp. 1703-1729.

Atkinson, G., Boore, D. (1995). New Ground Motion Relations for Eastern North America, Bull. Seismol. Soc. Am., Vol. 85, pp. $17-30$.

Bella, R.A. (2008), Pembuatan Program Interface Untuk Software USGS PSHA 2007 Dengan Studi Kasus Pembuatan Peta Spectra Hazard di Wilayah Nusa Tenggara Timur, Thesis Magister Teknik Sipil ITB
Boore, D.M. and Atkinson, G.M. (2008). Ground-motion Prediction Equations for the Average Horizontal Component of PGA, PGV, and 5\%-damped PSA at Spectral Periods between $0.01 \mathrm{~s}$ and 10.0 s, Earthquake Spectra, Vol. 24, no. 1.

BSN (2012), SNI 1726: 2012 Tata Cara Perencanaan Ketahanan Gempa untuk Struktur Bangunan Gedung dan Non Gedung, SNI 1726:2012, Badan Standardisasi Nasional, Jakarta.

Campbell, K.W. and Bozorgnia, Y. (2008). Ground Motion Model for the Geometric Mean Horizontal Component of PGA, PGV, PGD and 5\%-damped Linear Elastic Response Spectra for Periods Ranging from 0.01 to $10.0 \mathrm{~s}$, Earthquake Spectra, Vol. 24, no. 1.

Chiou, B. and Youngs, R. (1998). A NGA Model for the Average Horizontal Component of Peak Ground Motion and Response Spectra, Earthquake Spectra, Vol. 24, no. 1

Cornell, C.A. 1968. Engineering Seismic Risk Analysis, Bulletin of the Seismological Society of America, 58 (5), 1583-1606.

Gardner, J. K., \& Knopoff, L. (1974). Is the Sequence of Earthquakes in Southern California, With Aftershocks Removed, Poissonian?, Bulletin of the Seismological Society of America, 64, 1363-1367.

Gutenberg, B., \& Richter, C.F. (1944). Frequency of Earthquakes in California, Bulletin of the Seismological Society of America, 34, 185-188.

Hadiwidjojo, M.M., Samodra, H., dan Amin, T. C. (1998). Peta Geologi Lembar Bali Edisi Kedua. Pusat Penelitian dan Pengembangan Geologi.

Harmsen, S. (2010). USGS Software for Probabilistic Seismic Hazard Analysis (PSHA), United States of Geological Surveys (USGS).

J. Nugraha. (2014). Analisis Hazard Gempa dan Isoseismal untuk Wilayah JawaBali-NTB. J. Meteorol. Dan Geofis., vol. 15

Kurniawan, S., Warnana, D. D., dan Pandu, J. (2019). Pemetaan Kerawanan Bencana Gempa Bumi Dengan Metode PSHA Periode Ulang 2500 Tahun Studi Kasus 
Pulau Lombok - Nusa Tenggara Barat. Jurnal Geosaintek, Vol. 5 No. 3 Tahun 2019. 109-112. p-ISSN: 2460-9072, eISSN: 2502-3659

Pusgen, (2017). Peta Sumber dan Bahaya Gempa Indonesia Tahun 2017. Badan Penelitian dan Pengembangan Kementrian Pekerjaan Umum dan Perumahan Rakyat, ISBN 978-6025489-01-3.

Tim Revisi Peta Gempa Indonesia. (2010). Hasil Studi Revisi Peta Gempa Indonesia 2010. Laporan Studi.

Van der Werff, W. (1996). Variation in forearc basin development along the Sunda Arc, Indonesia. Journal of Southeast Asian Earth Sciences, 14(5), 331-349.
Wiemer, S. (2001). A Software Package to Analyze Seismicity: ZMAP, Seismological Research Letters, 72(2), 373-382.

Youngs, R.R., Chiou, S.J., Silva, W.J., Humphrey, J.R.. (1997). Strong Ground Motion Attenuation Relationships for Subduction Zone Earthquakes, Seismol. Res. Lett., Vol. 68, = pp. 58-73.

Zhao John, X., Zhang, J., Asano, A., Ohno, Y., Oouchi, T., Takahashi, T., Ogawa, H., Irikura, K., Thio, H., Somerville, P. (2006). Attenuation Relations of Strong Motion in Japan using Site Classification Based on Predominant Period, Bull. Seismol. Soc. Am., Vol. 96, pp. 898. 